Bangladesh J. Plant Taxon. 19(1): 25-31, 2012 (June)

(C) 2012 Bangladesh Association of Plant Taxonomists

\title{
FOLIAR EPIDERMAL CHARACTERS AND PETIOLE ANATOMY OF FOUR SPECIES OF CITRUS L. (RUTACEAE) FROM SOUTH-WESTERN NIGERIA
}

\author{
C.S. Ogundare And S.A. SAHEEd ${ }^{1}$ \\ Department of Botany, Faculty of Science, Obafemi Awolowo University, Ile-Ife 22005, Nigeria \\ Keywords: Citrus L.; Foliar characters; Petiole anatomy; Taxonomy; Nigeria.
}

\begin{abstract}
Studies on the leaf epidermal characters and petiole anatomy of four species of Citrus L. viz., C. limon (L.) Burm., C. paradisi Macf., C. reticulata Blanco and C. sinensis (L.) Osbeck were carried out to establish and document their foliar anatomical characters with the aim of separating them from the modified varieties been cultivated globally. Leaf epidermal features that revealed close relationship among these taxa include hypostomatic condition, stomata shape and type, presence of secretory cavity on the adaxial surface, and polygonal shape of epidermal cells. The absence of secretory cavity on the abaxial surface separates $C$. limon and $C$. sinensis from others. Petiole anatomy revealed that the outline is flat without ribs in $C$. sinensis, convex with short ribs in $C$. reticulata, convex with long ribs in C. paradisi while in C. limon it is circular without ribs. Presence of trichomes and crystals distinguishes $C$. paradisi from the rest.
\end{abstract}

\section{Introduction}

The genus Citrus L. is one of the very important genera in the family Rutaceae. They are shrubs or small to medium-sized trees and are cultivated throughout the tropics and subtropics. They are indigenous in some parts of India, China, Northern Australia and New Caledonia (Harley et al., 2006). Most Citrus species are of importance because of their fruits, which are eaten alone as fresh fruit, or they may be processed as fruit juice and in some cuisines, lemon, or lime are added to dishes and beverages. Most of the species in the genus have traditional medicinal value (Goethesson, 1997; Okeke and Mbagwu, 2001).

Due to increased economic value of Citrus species, many agricultural cultivars have been developed which has led to series of identity conflict between the parent plants and cultivars (Morton, 1987; Goldschmidt, 1996). Therefore, the phylogeny and taxonomy of Citrus remains a matter of controversy (Herrero et al., 1996). Citrus taxonomy is complex and unsettled, and a general assumption is that only three fundamental Citrus species exist while other species arose from hybridization (Katz and Weaver, 2003). However, which of the hybrids are considered species varies widely according to the classification scheme used (Katz and Weaver 2003). Interestingly, previous systematics of Citrus species rest on floral and fruit characters, only a few morphological and anatomical characters were considered (Morton, 1987; Goldschmidt, 1996). Many workers showed that Citrus leaves possess many morphological attributes of potential taxonomic significance that are often diagnostic at the genus and species levels (Arroyo, 1986; Edeoga and Eboka, 2000; Adedeji and Illoh, 2004; Mbagwu and Edeoga, 2006; Saheed and Illoh, 2010). The shape of epidermal cells, types and arrangement of stomata as well as the size and shape of trichomes are important taxonomic characters in this connection. The current study, therefore, is set to investigate detailed leaf epidermal and petiole anatomical characters of four selected parent species of Citrus, which may be of high diagnostic values that may further enhance the taxonomy of this important genus.

${ }^{1}$ Corresponding author. Email: saheed@oauife.edu.ng 


\section{Materials and Methods}

Fresh leaves of four species of Citrus namely, C. limon (L.) Burm., C. paradisi Macf., C. reticulata Blanco and $C$. sinensis (L.) Osbeck were collected from Obafemi Awolowo University Teaching and Research Farm Ile-Ife $\left(7^{\circ} 32^{\prime} \mathrm{N}, 4^{\circ} 32^{\prime}\right.$ E), Osun State, South West Nigeria. They were identified and confirmed at Obafemi Awolowo University Ile-Ife, Nigeria Herbarium (IFE). Epidermal peels of most of the specimens were obtained manually using forceps and dissecting needles, fragile and difficult materials were obtained using the procedure previously described (Adedeji and Jewoola, 2008). The peels were stained with 1\% Safranin ' $O$ ' solution for about 5-10 minutes, rinsed carefully in several changes of water to remove excess stains and then mount in dilute (10\%) glycerol solution on a glass slide for further microscopic observation. The transverse sections ( $20 \mu \mathrm{m}$ thick) of the leaf petiole were carefully cut through the median region using a sledge microtome following established protocols (Illoh, 1995; Essiett, 2010). The cut sections were placed on clean glass slides, stained with $1 \%$ Safranin 'O' mounted in dilute $(10 \%)$ glycerol. Microscopic observations of important leaf epidermal and petiole characters were viewed and captured on an Olympus BH-2 compound microscope fitted with a JVC KYF70B digital camera and selected images were imported as bitmaps to Corel Draw 12 (Corel Corporation, Ottawa, Canada 2003). Twenty-five measurements were taken for each of the measured parameters, guard cell area (GCA) was calculated by multiplying the length and width of guard cells by Franco's constant $(0.7854)$. Stomatal index $(\mathrm{SI})$ was obtained using the formula: $S I=[S /(E+S)] \times 100$; Where $\mathrm{S}=$ No. of stomata per unit area, $\mathrm{E}=$ No. of ordinary epidermal cell plus the subsidiary cells in the same unit area.

\section{Results}

\section{Leaf epidermal surface}

\section{C. limon (L.) Burm.}

On the adaxial surface the epidermal cells are largely polygonal (rectangular to pentagonal) with straight anticlinal walls (Fig. 1A). The walls are thick, having 3 or 4 layers of cells. The epidermal cells are 17.3-31.1 $\mu \mathrm{m}$ long and 6.9-13.8 $\mu \mathrm{m}$ broad. Stomata and trichomes are absent, but prismatic crystals and secretory cavities are present and they are distributed throughout the surface of the epidermis. The shape of the epidermal cells on the abaxial surface is the same as on the adaxial with straight anticlinal walls (Fig. 1B). The cells are arranged in elongated rows, the walls are thick with 3 or 4 layers of cells and are 13.8-44.9 $\mu \mathrm{m}$ long and $6.9-13.8 \mu \mathrm{m}$ broad. Stomata are abundant, largely paracytic, circular or elliptic in shape. The size of the stomata is $47.6-285.7 \mu \mathrm{m}^{2}$ and the stomata index is between $11.2 \%$ and $23.7 \%$. Prismatic crystals are present and distributed throughout the surface while secretory cavity is absent.

\section{C. paradisi Macf.}

The adaxial epidermal cells are largely polygonal (rectangular to pentagonal) with straight anticlinal walls (Fig. 1C). The walls are thick having 3 or 4 layers of cells and these are 13.8-31.1 $\mu \mathrm{m}$ long and 6.9-17.3 $\mu \mathrm{m}$ wide. The species is hypostomatic, but prismatic crystals and secretory cavities occur on this surface and they are distributed throughout the surface. The epidermal cells have straight anticlinal walls and the cells are arranged in elongated rows (Fig. 1D). The walls are thick having 3 or 4 layers of cells, cells are 13.8-38.0 $\mu \mathrm{m}$ long and 6.9-13.8 $\mu \mathrm{m}$ wide. Stomata are abundant and are largely paracytic circular with few been elliptic, their size is $71.8-285.7 \mu \mathrm{m}^{2}$ and stomata index ranges between $17.1 \%$ and $24.2 \%$. Prismatic crystals and secretory cavities are present and distributed throughout the surface. 

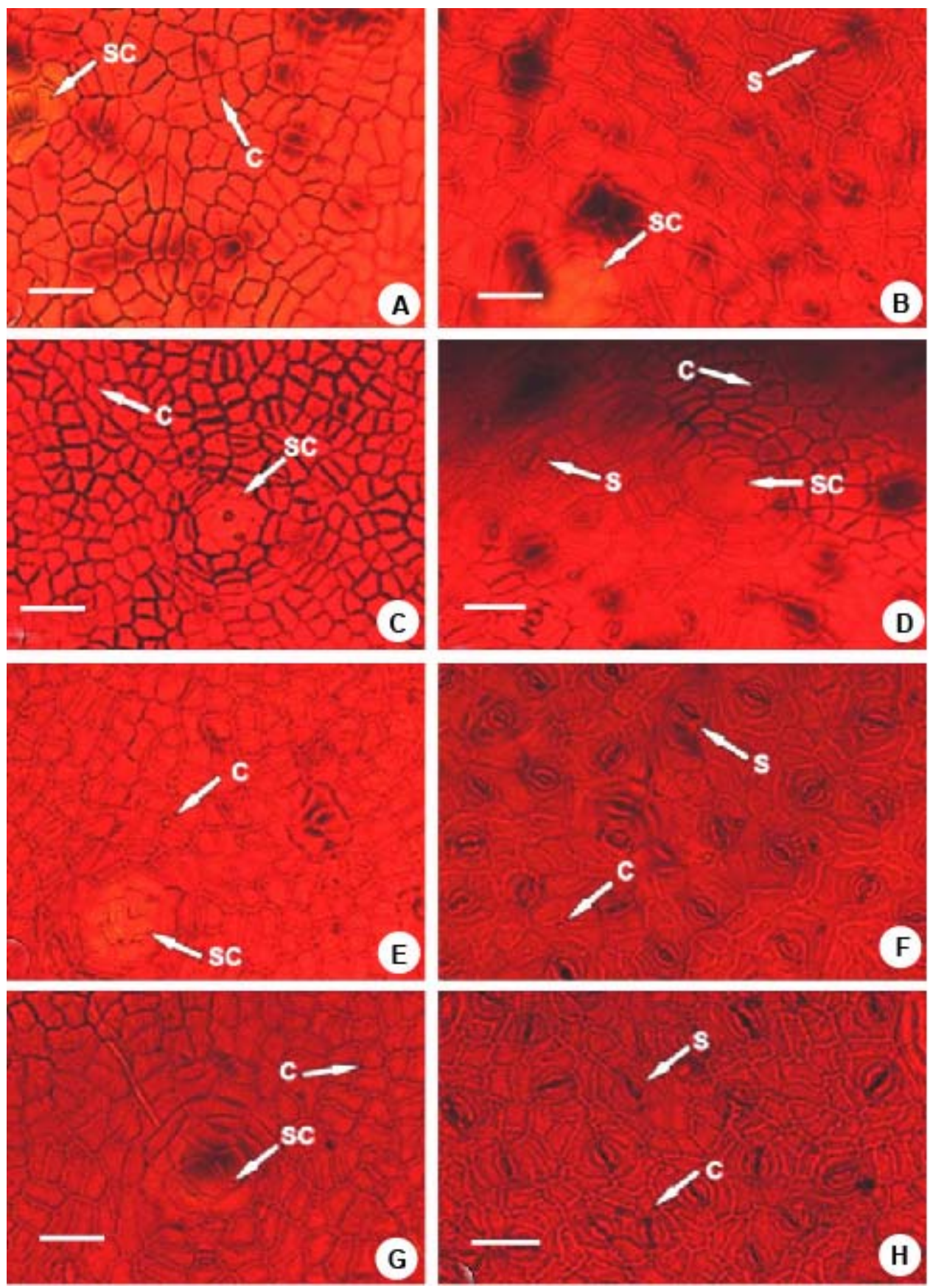

Fig. 1. Adaxial and abaxial epidermal surfaces of Citrus species. C. limon, A) adaxial, B) abaxial; C. paradisi, C) adaxial, D) abaxial; C. reticulata, E) adaxial, F) abaxial; C. sinensis G) adaxial, H) abaxial. $\mathrm{C}=$ crystals; $\mathrm{S}=$ stomata; $\mathrm{SC}=$ secretory cavity. Scale $=21 \mu \mathrm{m}$. 


\section{C. reticulata Blanco}

Adaxial epidermal cells are largely polygonal (rectangular to pentagonal), anticlinal walls are straight, cell wall are 3 or 4 layers thick (Fig. 1E). Ordinary epidermal cells are 13.8-38.0 $\mu \mathrm{m}$ long and 6.9-17.3 $\mu \mathrm{m}$ wide. Stomata and trichomes are absent. Prismatic shaped crystals and secretory cavity are present and they are distributed throughout the surface of the epidermis. Epidermal cells on the abaxial surface (Fig. 1F) are largely polygonal (rectangular to pentagonal). Anticlinal walls are straight and are 3 or 4 layers thick with epidermal cells arranged in elongated rows. Epidermal cells are 17.3-41.4 $\mu \mathrm{m}$ long and 6.9-17.3 $\mu \mathrm{m}$ wide. Paracytic stomata are abundantly present circular in shape with few been elliptic. Stomata index is between $13.0 \%$ and $22.0 \%$, stomata size is $71.8-238.7 \mu \mathrm{m}^{2}$. Prismatic crystals and secretory cavity are present distributed throughout the surface while trichomes are absent.

\section{C. sinensis (L.) Osbeck}

Epidermal cells on adaxial surface are largely polygonal, rectangular to pentagonal, with straight anticlinal walls (Fig. 1G). The walls are 3-4 layers thick, and the cells are 20.7-38.0 $\mu \mathrm{m}$ long and 10.4-17.3 $\mu \mathrm{m}$ broad (Table 1). Stomata and trichomes are generally absent but there are prismatic crystals as well as secretory cavities distributed throughout the surface. On the abaxial surface (Fig. 1H), epidermal cells are largely polygonal just like it is on the adaxial surface, with straight anticlinal walls and they are 3 or 4 layers thick. The epidermal cells are 17.3-44.9 $\mu \mathrm{m}$ long and 10.4-20.7 $\mu \mathrm{m}$ broad. Paracytic stomata occur in abundant largely circular in shape with few been elliptic. Stomata index ranges between $12.2 \%$ and $25.7 \%$, while stomata size is $143.5-358.1$ $\mu \mathrm{m}^{2}$. Prismatic crystals are distributed throughout the surface but without secretory cavity.

Table 1. Leaf epidermal and petiole anatomical characters of four species of Citrus $\mathbf{L}$.

\begin{tabular}{|c|c|c|c|c|c|c|c|c|c|c|}
\hline \multirow{2}{*}{ Species } & \multicolumn{2}{|c|}{$\begin{array}{l}\text { Adaxial } \\
\text { Surface }\end{array}$} & \multicolumn{4}{|c|}{ Abaxial Surface } & \multicolumn{4}{|c|}{ Petiole } \\
\hline & $\begin{array}{l}\mathrm{CS}(\mu \mathrm{m}) \\
\mathrm{L} / \mathrm{W}\end{array}$ & $\mathrm{SC}$ & $\begin{array}{l}\mathrm{CS}(\mu \mathrm{m}) \\
\mathrm{L} / \mathrm{W}\end{array}$ & $\mathrm{SS}\left(\mu \mathrm{m}^{2}\right)$ & SI (\%) & $\mathrm{SC}$ & Outline & $\mathrm{TC}$ & $\mathrm{SC}$ & $\mathrm{C}$ \\
\hline C. limon & $\begin{array}{l}17.3-31.1 \\
6.9-13.8\end{array}$ & + & $\begin{array}{l}13.8-44.9 \\
6.9-13.8\end{array}$ & $47.6-285.7$ & $11.2-23.7$ & - & $\begin{array}{l}\text { Circular, } \\
\text { no ribs }\end{array}$ & - & - & - \\
\hline C. paradisi & $\begin{array}{l}13.8-31.1 \\
6.9-17.3\end{array}$ & + & $\begin{array}{l}13.8-38.0 \\
6.9-13.8\end{array}$ & $71.8-285.7$ & $13.0-22.7$ & + & $\begin{array}{l}\text { Convex, } \\
\text { long ribs }\end{array}$ & + & + & + \\
\hline C. reticulata & $\begin{array}{l}13.8-38.0 \\
6.9-17.3\end{array}$ & + & $\begin{array}{l}17.3-41.4 \\
6.9-17.3\end{array}$ & $71.8-238.7$ & $17.1-24.2$ & + & $\begin{array}{l}\text { Convex, } \\
\text { short ribs }\end{array}$ & - & - & - \\
\hline C. sinensis & $\begin{array}{l}20.7-38.0 \\
10.4-17.3\end{array}$ & + & $\begin{array}{l}17.3-44.9 \\
10.4-20.7\end{array}$ & $143.5-358.1$ & $12.2-25.7$ & - & $\begin{array}{l}\text { Flat, no } \\
\text { ribs }\end{array}$ & - & - & - \\
\hline
\end{tabular}

$\mathrm{CS}=$ cell size; $\mathrm{L}=$ length $; \mathrm{W}=$ width $; \mathrm{SC}=$ secretory cells; $\mathrm{SS}=$ stomata size; $\mathrm{SI}=$ stomata index; $\mathrm{TC}=$ trichomes; $\mathrm{C}=$ crystals; + = present; - = absent.

\section{Petiole Anatomy}

C. limon (L.) Burm.

Median region outline is circular without ribs and trichomes (Fig. 2A). The epidermis is uniseriate. The cortex contains 4 to 7-layered angular collenchyma cells on the outermost region of the petiole, followed by 10 to 14-layered parenchyma cells. A layer of sclerenchyma cell surrounds the vascular bundles which form a continuous ring. Shining crystals and 1 or 2 layers of 
secretory cells are present. The collateral vascular bundles are arranged in a ring form and joined together. The pith is parenchymatous and embedded with prismatic crystals.

\section{C. paradisi Macf.}

The outline of the median region is convex with long ribs and short, unicellular, nonglandular, unbranched trichome is present (Fig. 2B). The epidermis is uniseriate. Angular collenchyma of 4-6 layers cells occur on the outermost portion of the cortex followed by 6 to 8 layered parenchyma cells. A layer of sclerenchyma cells forms a continuous ring round the vascular bundles, secretory cells are absent. Collateral vascular bundles are arranged in a ring form and are joined together. The pith is parenchymatous without crystals.
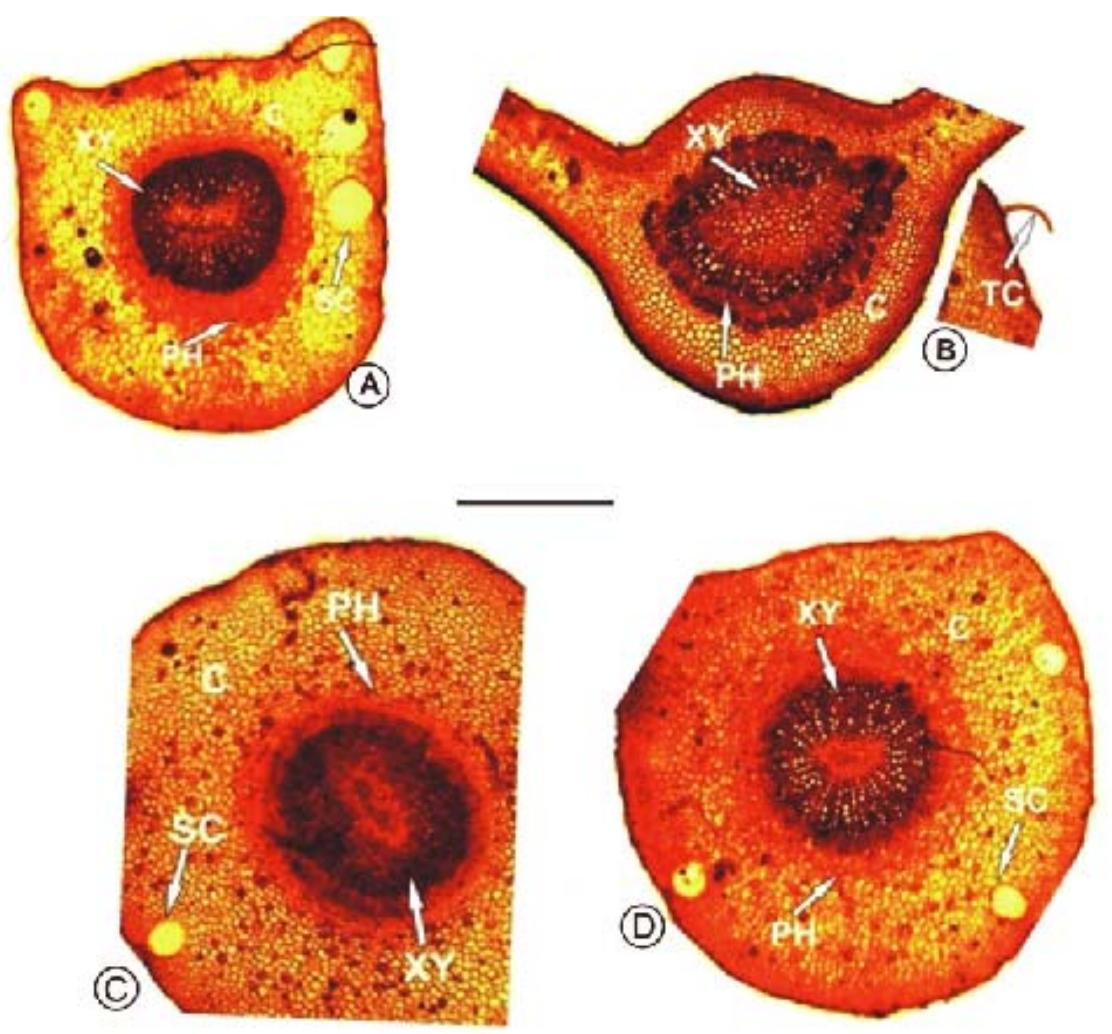

Fig. 2. Anatomical features found in the petiole of Citrus species. A) C. limon; B) C. paradisi; C) C. reticulata; D) C. sinensis. $\mathrm{C}=$ cortex; $\mathrm{XY}=$ xylem; $\mathrm{PH}=$ phloem; $\mathrm{SC}=$ secretory cavity; $\mathrm{TC}=$ trichome. Scale $=25 \mu \mathrm{m}$.

\section{C. reticulata Blanco}

The median region outline is convex with short ribs (Fig. 2C). Trichomes are absent while the epidermis is uniseriate. The cortex contains 3 to 5-layered angular collenchyma cells to the outermost portion, followed by 5 to 7-layered parenchyma cells. A layer of sclerenchyma cells forms a continuous ring around the vascular bundles, with shining prismatic crystals and 3 or 4 layers of secretory cells. Collateral vascular bundles are arranged in a ring joining one another, the pith is parenchymatous without crystals. 


\section{C. sinensis (L.) Osbeck}

The outline through the median region is flat without ribs (Fig. 2D). Trichomes are absent and the epidermis is uniseriate. The cortex contains 4 to 6-layered angular collenchyma cells to the outermost portion, followed by 8 to 12-layered ordinary parenchyma cells. A layer of sclerenchyma surrounds the vascular bundles forming a discontinuous ring around it. Prismatic and shining crystals are present in the cortical region along with 2 or 3-layered secretory cells. Collateral vascular bundles are arranged in a ring form and are fused together. The pith is parenchymatous with prismatic crystals embedded in it.

\section{Discussion}

The present study showed that foliar epidermal and petiole anatomical features are useful for characterization and delimitation of the four species of Citrus studied. All the species investigated have very similar foliar epidermal characters with only few differences which points to the close inter-relationship among them. On both adaxial and abaxial surfaces epidermal cells are largely polygonal (rectangular to pentagonal) and the anticlinal walls are straight for all the species (Table 1). The epidermal wall is 3 or 4 layers thick with secretory cavities and prismatic crystals occurring on the epidermal surfaces of all the species except in C. sinensis and C. limon where secretory cavities are found only on the adaxial but absent on their abaxial surfaces. However, the size of the ordinary epidermal cells on both surfaces varies among the species (Table 1).

Our result also shows that the epidermal cells of $C$. sinensis appear bigger in size and it is characteristics of this species when compared to others. Illoh (1995), Adedeji and Jewoola (2008), and Saheed and Illoh (2010) have shown that the varying sizes of foliar epidermal cells in plants could be characteristics and delimiting among closely related species. Presence of the hypostomatic nature in all the four species of Citrus (Table 1) is probably an adaptation to water loss (Shaw, 1977; Goldschmidt, 1996) as it is expected to confer an ecological advantage to survive as perennial plants. Paracytic stomata are encountered in all the four species and they are mostly circular with few elliptic in all the species studied. The stomata size in $C$. sinensis was found to be the highest like the ordinary epidermal cells while it is smallest in C. reticulata. Stomata index equally varies, yet $C$. sinensis has the highest and with others closely ranged. The data from our work clearly show that foliar epidermal characters could be employed to distinguish closely related species of Citrus. Our findings support previous studies in some other genera where leaf anatomical characters have been used as a veritable taxonomic tool (Ogundipe and Olatunji, 1991; Illoh, 1995; Adedeji and Illoh, 2004; Saheed and Illoh, 2010; Akcin and Binzet, 2010).

Petiole anatomy has been reported to provide considerable variations which are of taxonomic significance (Olatunji and Bakare, 1993; Srinual and Thammathaworn, 2008; Essiet, 2010). Our results shows clear distinguishing general outline of the median regions of the petiole, the outline is flat without ribs in C. sinensis, convex with short ribs in C. reticulata, convex with long ribs in C. paradisi, while the outline of C. limon is circular without ribs. Trichome is absent in C. limon, C. reticulata and C. sinensis, but present only in C. paradisi. The petiole epidermal cells are uniseriate along with angular collenchyma cells in the cortex of all four species. Struwig et al. (2011) have shown that the number of chlorenchyma rows may be diagnostic in some other genera. Our results have shown that the number of collenchyma layers though overlapping, may still be diagnostic to some extent considering the minimum and maximum number of layers that can be found in the species investigated. The presence of crystals in the pith and cortical regions is quite delimiting. Crystals occurs in both the pith and cortical regions of $C$. sinensis and C. limon, but present in the cortical region only in C. reticulata, while crystals are completely absent in both regions in C. paradisi. This work has provided basic information on foliar epidermal characters 
and detailed petiole anatomical attributes that show close relationships between four Citrus species as well as distinguishing characters which could be employed to identify these native species from their improved cultivars.

\section{References}

Adedeji, O. and Illoh, H.C. 2004. Comparative foliar anatomy of 10 species in the genus Hibiscus Linn. in Nigeria. New Botanists 31: 147-180.

Adedeji, O. and Jewoola, O.A. 2008. Importance of leaf epidermal characters in the Asteraceae family. Not. Bot. Hort. Agrobot. Cluj. 36(2): 7-16.

Akçin, Ö.E. and Binzet, R. 2010. The micromorphological and anatomical properties of Onosma angustissimum Hausskn. \& Bornm. and O. cassium Boiss. (Boraginaceae). Bangladesh J. Plant Taxon. 17(1): $1-8$.

Arroyo, S. 1986. Leaf anatomy in the Tecophilaeaceae. Bot. J. Linn. Soc. 93: 323 -328.

Edeoga, H.O. and Eboka, A.U. 2000. Morphology of the leaf epidermis and systematics in some Dissotis Benth. species (Melastomataceae). Global J. Pure Appl. Sci. 6(3): 371-374.

Essiett, U.A. 2010. Petiole anatomy for systematic purposes in Eremomastas polysperma, Justicia insularis and Asystacia gangetica (Acanthaceae). World J. Appl. Sci. Tech. 2(1): 69-75.

Goethesson, L.C. 1997. Plants of the Pitcairn islands including local names and uses. Centre for South Pacific Studies, University of New South Wales, Sydney, Australia.

Goldschmidt, E.E. 1996. Biology of Citrus. Cambridge University Press, Cambridge, UK.

Harley, M.I., Richard, B.S., Virginia, E.S., Ward, D. and Elevitch, C.R. 2006. Citrus (citrus) and Fortunella (kumquat) Rutaceae (Rue Family) In: Elevitch, C.R. (ed.). Species Profile for Pacific Island Agroforestry. Permanent Agriculture Resources, (PAR), Hōlualoa Hawai‘i , pp. 1-27.

Herrero, R., Asíns, M.J., Carbonell, E.A. and Navarro, L. 1996. Genetic diversity in the orange subfamily Aurantioideae. I. Intraspecies and intragenus genetic variability. Theor. Appl. Gen. 92(5): 599-609.

Illoh, H.C. 1995. Foliar epidermis and petiole anatomy of four species of Celosia L. in Nigeria. Feddes Repert. 106(1-2): 15-23.

Katz, S.H. and Weaver, W.W. 2003. Encyclopedia of Food and Culture. Schribner, New York.

Mbagwu, F.N. and Edeoga, H.O. 2006. Leaf anatomy of some Nigerian species of Vigna savi (LeguminosaePapilionoideae). Agri. J. 1(1): 5-7.

Morton, J. 1987. In: Morton, J.F. (ed.), Fruits of Warm Climates. Miami, Florida.

Ogundipe, O.T and Olatunji, O.A 1991. The leaf anatomy of the species of Cochlospermum Kunth. (Coschlospermaceace) in West Africa. Feddes Repert. 102(3-4): 183-187.

Okeke, S.E. and Mbagwu, F.N. 2001. Herbalism in Njaba local government area of Imo State of Nigeria. J. Sci. Eng. Tech. 2: 168-174.

Olatunji, A.O. and Bakare, O.A. 1993. Taxonomic value of the petiole anatomy in the genus Sida L. (Malvaceae) in Nigeria. Feddes Repert. 104(1-2): 35-39.

Shaw, P.E. 1977. Essential Oils. In: Nagy, S., Shaw, P.E. and Veldhuis, M.K. (eds), Citrus Science and Technology. Westport, CT, The AVI Publishing Co. Inc., 427 pp.

Saheed, S.A. and Illoh, H.C. 2010 A taxonomic study of some species in Cassinae (Leguminosae) using leaf epidermal characters. Not. Bot. Hort. Agrobot. Cluj 38(1): 21-27.

Srinual, A. and Thammathaworn, A. 2008. Leaf anatomy of Vatica L. (Dipterocarpaceae) in Thailand. Nat. Hist. J. Chulalongkorn Uni. 8(2): 121-134.

Struwig, M., Jordaan, A. and Siebert S.J. 2011 Anatomy of the southern African Boerhavia and Commicarpus species (Nyctaginaceae) Bangladesh J. Plant Taxon. 18(2): 105-115.

(Manuscript received on 25 October 2011; revised on 27 May 2012) 